\title{
Using the False Claims Act as a Basis for Institutional Review Board Liability
}

\author{
Daniel J. Powell $\uparrow$
}

In recent years, several major incidents involving human subjects research, two involving the death of the subject, have shaken confidence in the protections afforded human subjects of biomedical research.' For instance, officials at Johns Hopkins University were recently chastised by a state court for allegedly exposing children to potentially harmful lead-based paint. ${ }^{2}$ In two other instances, a New Jersey law firm has filed suit on behalf of the subjects. ${ }^{3}$ In addition to naming the research institution and the researcher as defendants, these plaintiffs took the highly unusual step of suing the Institutional Review Board ("IRB"), a peer-review board that studied the safety and efficacy of the proposed research program and was responsible for approving it for federal funding. ${ }^{4}$ While there is some precedent for this type of suit, the theories on which such a suit could be predicated have not been fully discussed or explored, as few suits against an IRB have ever gone to trial.

The most straightforward suit is, of course, a tort suit alleging negligence on the part of the IRB in approving the research protocol. Other theories of liability have been pursued, including allegations of infringements of constitutional rights and violations of the federal laws and regulations governing the proper conduct of federally funded research involving human participants. This Comment argues that

\footnotetext{
$\dagger$ A.B. 2000, Princeton University; J.D. Candidate 2003, The University of Chicago.

1 Michael D. Lemonick and Andrew Goldstein, At Your Own Risk, Time 46 (Apr 22, 2002) (describing several research studies and the public perception surrounding clinical trials).

2 See text accompanying notes $43-46$.

3 The complaints are available online at $<\mathrm{http} / / / \mathrm{www} . s s k r p l a w . c o m / g e n e>$ (visited Dec 10, 2001).

4 Id.

5 Mary R. Anderlink and Nanette Elster, Currents in Contemporary Ethics: Lawsuits Against IRBs: Accountability or Incongruity?, 29 J L Med \& Ethics 220, 224 \& n 54 (2001) (citing the complaint filed in Robertson $v$ McGee, No 01CU0060HCM (N D Okla 2001); Kus v Sherman Hospital, 268 Ill App 3d 771, 644 NE2d 1214, 1216 (1995) (involving a suit against an IRB for failing to monitor whether a physician was obtaining proper informed consent from his patients, who were subjects in an experiment).

6 Robert J. Katerberg, Institutional Review Boards, Research on Children, and Informed Consent of Parents: Walking the Tightrope Between Encouraging Vital Experimentation and Protecting Subjects' Rights, 24 J Coll \& Univ L 545, 574 n 156 (1998) (finding only two cases in the literature, neither of which was reported).
} 
plaintiffs have another tool at their disposal: the federal False Claims Act ("FCA")."

The FCA is increasingly being deployed, both by the government and private individuals, to enforce regulatory requirements in other areas of health care law, most notably Medicare reimbursement regulations and fraud and abuse laws. ${ }^{8}$ Although suits against IRBs have not alleged a cause of action under the FCA, at least one commentator has suggested the possibility. In addition, while no decisions have been reached on the merits, two suits have alleged a violation of the FCA for the failure of a university to adhere to the federal regulations governing human subjects research.'

This Comment discusses the FCA in relation to suits against IRBs. Part I explains the regulatory framework within which IRBs must operate, as well as the structure of the human subject protection system. This Part also describes several of the most recent incidents involving human subjects research in the United States. Part II provides an overview of the essential elements of a suit under the FCA, focusing upon the application of the FCA to fraud and abuse laws, which provide the closest analogy to IRB regulations and present similar issues. Finally, Part III suggests that as a matter of both law and policy, courts should allow FCA claims against the IRB in very limited circumstances, using the four cases from Part I to illustrate the application of the suggested interpretations. Part III will also include a discussion of the limited instances in which the suits might be useful in strengthening the human subjects protection system.

\section{HuMAN SubJects ReSEARCH IN THE UNITED STATES}

This Part examines the current environment in which an FCA suit against an IRB would be brought. Part I.A provides background on the human research protection system in place in the United States and focuses on provisions found in the federal regulations, with which compliance is required to receive federal funding. Part I.B discusses

$7 \quad 31$ USC \$§ 3729-33 (1994 \& Supp 2001).

8 Government statistics show that in 1987,12 percent of all qui tam actions involved a program operated through the Department of Health and Human Services ("HHS"), the department responsible for administering many health care laws and programs. Pamela H. Bucy, Growing Pains: Using the False Claims Act to Combat Health Care Fraud, 51 Ala L Rev 57, 58 (1999). By 1998, however, that number had increased to 61 percent. Id.

9 Zissler $v$ Regents of the University of Minnesota, 154 F3d 870,871 (8th Cir 1998) (noting that the plaintiff brought an FCA claim against the defendant hospital for false and misleading statements in administering a federal grant); Chandler $v$ Hektoen Institute for Medical Research, 35 F Supp 2d 1078, 1079-80 (N D Ill 1999) (explaining that the plaintiff brought an FCA claim against the defendant hospital for failing to comply with federal grant requirements and misrepresenting its progress). 
several clinical research trials in which the human subject regulations described in Part I.A were apparently violated.

\section{A. Regulatory Framework}

In 1974, Congress passed the National Research Act, ${ }^{10}$ which overhauled the system of protection for human subjects enrolled in biomedical and behavioral research. The provision that had the greatest effect was the requirement that all federally funded research receive IRB approval." Largely as a result of this law, most institutions that conduct federally funded research now have an IRB, which is composed of at least five members ${ }^{12}$ and must include at least one scientific member, one member who is primarily concerned with nonscientific issues, and one member who is not affiliated with the research institution. ${ }^{13}$

Pursuant to the National Research Act, the Secretary of Health and Human Services ("HHS") has established an elaborate system for approving federally funded research. Under this system, the Office of Human Research Protections ("OHRP") is charged with developing and ensuring compliance with HHS regulations, as well as negotiating assurances with institutions conducting human subjects research. ${ }^{14}$ OHRP requires these assurances, called Federal Wide Assurances ("FWAs"), before it will allow an IRB to review any human subjects research. "These assurances memorialize an institution's commitment to protecting human subjects. ${ }^{16}$ By signing a FWA, an institution agrees that all research performed in the institution will adhere to The Belmont Report ${ }^{17}$ or a similar statement of ethical principles. ${ }^{18}$ Further-

10 Pub L No 93-348, 88 Stat 342, codified at 42 USC \$\$ 289-300aaa-13 (1994).

1142 USC $\$ 289$ (a).

1245 CFR $\$ 46.107$ (a) (2000).

1345 CFR $\$ 46.107$ (c) - (d).

1465 Fed Reg 37136-37 (2000). Until June 2000, the Office of Protection from Research Risks ("OPRR"), a department within the National Institutes of Health ("NIH"), oversaw the system created by the Federal Regulations and had substantially the same authority as OHRP. Id; Medical Research: Edward Greg Koski Selected to Head New Office for Protection of Human Subjects, BNA Health Care Daily D15 (June 7, 2001). Even where incidents occurred before OPRR was changed to OHRP, the Comment will refer to OHRP for consistency.

15 The FWA replaces the Multiple Project Assurance and the Single Project Assurance, either of which was required to conduct federally funded human subjects research prior to 2001 . HHS, IRB Registration and Insurance Filing Procedures: General Information, available online at <http://ohrp.osophs.dhhs.gov/humansubjects/assurance/refinfo.htm\#WHAT> (visited Mar 20, 2002).

16 Id.

17 The National Commission for the Protection of Human Subjects of Biomedical and Behavioral Research ("Commission") was charged with developing ethical guidelines for human subjects research. The Commission did so in what has become the foundation of modern bioethical principles and the document responsible for many of the protections currently in place regarding human subjects research, The Belmont Report: Ethical Principles and Guidelines for 
more, it agrees to submit all federally funded research to an IRB and assures that such research will adhere to federal guidelines. ${ }^{19}$ If OHRP finds that a particular researcher or the IRB has not adhered to the federal guidelines, it may: limit the types of research protocols that the FWA covers; revoke the FWA; or recommend that an individual researcher, or a research institution, be temporarily or permanently forbidden from conducting research involving human subjects. ${ }^{20}$

HHS has issued regulations governing research involving human subjects, the so-called Common Rule. ${ }^{21}$ The focus of the Common Rule is the IRB, which is primarily charged with balancing the risks and benefits of the research, ensuring an equitable selection of subjects, and obtaining valid informed consent of the human participants. ${ }^{2 .}$ The IRB must also continually review research protocols to ensure that they are in compliance with federal regulations ${ }^{23}$ and may suspend or terminate its approval of the research if there has been unanticipated harm to subjects or if the researcher is failing to abide by the Common Rule. In many ways the IRB is the linchpin of the federal system for protecting human subjects. As a committee charged in part with examining the system of human subjects research put it: "[T]he IRB is the enforcing agent of federal protections that is situated closest to the conduct of research. Much of the success or failure of the federal regulations governing human research depends on the effectiveness of IRBs in carrying out their responsibilities." ${ }^{25}$

the Protection of Human Subjects of Research, DHEW Pub No (OS) 78-0012 (GPO 1978).

18 HHS, Federalwide Assurance of Protection for Human Subjects for Domestic (US) Institutions, available online at <http://ohrp.osophs.dhhs.gov/humansubjects/assurance/filasur.htm> (visited Mar 20, 2001) (noting in the "Statement of Principles" section that another document containing guiding principles might be acceptable).

19 Id.

20 Robert Fabrikant, et al, Health Care Fraud: Criminal, Civil, and Administrative Law $\$ 2.04$ (discussing the process of applying for and receiving federal research funds), available on Westlaw at HTHCRFRD $\S 2.04$.

2145 CFR $\S 46$ (2000). In actuality, each department of the federal government has separately adopted the Common Rule, so it appears numerous times in the CFR. See 56 Fed Reg 28012 (1991) for a listing of the applicable sections for each department. The Food and Drug Administration ("FDA"), however, has not adopted the Common Rule and operates under a slightly different set of regulations. See 21 CFR $\$ 50$ (2001). There are a few substantive differences between the Common Rule and the FDA regulations, but none matter for the purposes of this Comment. Therefore, this Comment will use the terms "Common Rule" and "federal regulations" interchangeably.

2245 CFR \$ 46.111.

2345 CFR $\$ 46.109(\mathrm{e})$.

$24 \quad 45$ CFR $\$ 46.113$.

25 Ruth R. Fadin, et al, Final Report of the Advisory Committee on Human Radiation Experiments (ACHRE) 430 (Oxford 1996). 
B. Recent Research Mishaps

Four recent cases, two of which involved the death of a human subject, have sharpened the focus on the activities of IRBs in approving research. In three of those instances, OHRP has established that federal guidelines were violated, and it is still investigating the fourth.

1. The Gelsinger case.

On September 17, 1999, eighteen-year-old Jesse Gelsinger died while in a gene therapy trial sponsored by the University of Pennsylvania. ${ }^{26}$ Although Gelsinger had a form of the disease being treated, he was not expected to benefit from the treatment itself, which focused on examining the efficacy of a treatment that might eventually be used on babies with a fatal form of the disease. In an investigation following Gelsinger's death, officials concluded that Gelsinger did not meet the criteria for participating in the study and should never have been enrolled. ${ }^{23}$ Officials also concluded that adverse events were not immediately reported to the IRB in violation of the federal regulations. Perhaps most importantly, the lead investigator had a conflict of interest that was never disclosed to the patient. ${ }^{30}$ Although Gelsinger's family initially supported the actions of those involved, they eventually filed suit against the university.

\section{The Robertson case.}

Another high-profile case occurred in 2000 at the University of Oklahoma Health Sciences Center-Tulsa. A nurse familiar with the particulars of an ongoing cancer vaccine trial alleged numerous deviations from the federal regulations in that study. ${ }^{33}$ OHRP confirmed these allegations, finding that the chair of the IRB unilaterally approved retroactive changes in the research protocol, rather than ob-

26 Nicholas Wade, Death Leads to Concerns for Future of Gene Therapy, NY Times A22 (Sept 30,1999).

27 Sheryl Gay Stolberg, FDA Officials Fault Penn Team in Gene Therapy Death, NY Times A22 (Dec 9, 1999).

28 Id.

29 Id.

30 Jennifer Washburn, Informed Consent: Alan Milstein Says He Wants to Rescue Us from Unscrupulous Doctors, Undisclosed Risks and Greedy Institutions. But Is He a Shining Knight, or an Enemy of Medical Progress?, Wash Post Mag W16 (Dec 30, 2001) (noting that the lead investigator had entered into a relationship with a biotechnology company -in which he also held stock-that agreed to fund 20 percent of annual research costs in exchange for the right to develop commercial uses of the investigator's research).

31 Stolberg, FDA Officials at A22 (cited in note 27).

32 Anderlink and Elster, $29 \mathrm{~J} \mathrm{~L} \mathrm{Med} \mathrm{\&} \mathrm{Ethics} \mathrm{at} 220$ (cited in note 5).

33 Id at 221. 
taining the vote of the full IRB. ${ }^{34}$ OHRP also found that the requirement of continuing review was satisfied for very few of the protocols and that the board lacked sufficient information to make the required findings to protect vulnerable populations, maintain privacy and confidentiality, and ensure the equitable selection of subjects. ${ }^{35}$ As a result of these findings, OHRP shut down the research trial. ${ }^{36}$ Several patients subsequently filed suit against those involved, including members of the IRB. ${ }^{37}$ In their complaint (containing 122 causes of action), the plaintiffs alleged that the IRB violated their right to dignity and other civil rights, failed to adhere to the federal regulations, and behaved negligently in the conduct of the research trial.

\section{The Ellen Roche case.}

In the summer of 2001, Johns Hopkins University was the subject of an OHRP investigation after Ellen Roche, a healthy, twenty-fouryear-old volunteer, died from her participation in an asthma study. ${ }^{39}$ In addition to faulting the researcher for inadequately researching the drug used in the study, ${ }^{40}$ OHRP cited the Hopkins IRB for significant violations of the federal regulations. Specifically, the IRB failed to obtain adequate information to evaluate the risks of the research proto$\mathrm{col}$, did not sufficiently review ongoing research, failed to fully consider the needs of vulnerable subjects, and kept insufficient records of its meetings." As a result of these violations, OHRP terminated all

34 See 45 CFR $\S 46.109$ (a) (requiring IRB approval of all research activities covered by the federal regulations).

35 Anderlink and Elster, $29 \mathrm{~J} \mathrm{~L} \mathrm{Med} \mathrm{\&} \mathrm{Ethics} \mathrm{at} 221$ (cited in note 5).

36 Id.

37 Chad Bowman, Professional Liability: Subjects in Halted Melanoma Trial Sue Institutional Review Board, Others, BNA Health Care Daily Report d7 (Feb 2, 2001).

38 First Amended Complaint, Robertson $v$ McGee, available online at <http://www. sskrplaw.com/gene/robertson/complaint-new.html> (visited Mar 21, 2000).

39 Associated Press, Report on a Research Death Faults Review Board, NY Times A16 (Aug $31,2001)$.

40 Letter from Patrick J. McNeilly, Compliance Oversight Coordinator, Division of Compliance Oversight, HHS, and Michael Carome, Director, Division of Compliance Oversight, HHS, to Edward Miller, Dean and Chief Execuitive Officer, Johns Hopkins Medicine, Chi Van Dang, Vice Dean for Research, The Johns Hopkins University School of Medicine, and Gregory F. Schaffer, President, The Johns Hopkins Bayview Medical Center, July 19, 2001, available online at <http://ohrp.osophs.dhhs.gov/detrm_letrs/jul01a.pdf> (visited Mar 21, 2002). It appears that previous versions of textbooks had indicated that the drug used to induce asthma was toxic in humans, and that a more exhaustive review of the literature would have revealed that the research protocol should have been modified. Letter from Chi Van Dang, Vice Dean for Research, Johns Hopkins University School of Medicine, and Gregory F. Schaffer, President, Johns Hopkins Bayview Medical Center, to Michael Carome, Division of Compliance Oversight, OHRP, July 13, 2001, available online at <http://www.sunspot.net/bal-hopkinsletters.htmlstory $>$ (visited Feb 7, 2002).

41 Letter from Patrick J. McNeilly (cited in note 40). 
federally funded research at Hopkins for several days while officials at Hopkins formulated a plan to address OHRP's concerns.

\section{The Grimes case.}

More recently, a lawsuit was filed in response to another incident at Johns Hopkins, this time involving research aimed at determining the effect of partial lead abatement procedures. ${ }^{43}$ Despite knowing that such exposure could be dangerous, researchers encouraged landlords participating in the study to rent to families with young children and periodically measured the lead content in the blood of children who lived in the study houses, comparing it to the amount of lead dust in the home. ${ }^{44}$ Furthermore, it appears that the IRB did not require the researchers to obtain informed consent, and suggested word modifications in the research protocol that would hide the fact that children were acting as a control group, a practice discouraged by the federal regulations. ${ }^{45}$ Based on these facts, the Maryland Court of Appeals overruled a Maryland district court and held that the plaintiffs stated a cause of action. After their decision was handed down, OHRP initiated an investigation of the research. ${ }^{46}$

\section{THE FEDERAL FALSE CLAIMS ACT}

Before evaluating these cases under the FCA, an examination of the FCA itself is warranted. Part II.A provides a general overview of the FCA, including its history as well as the required elements of a successful suit. Part II.B discusses the application of the FCA to fraud and abuse laws in the health care field ${ }^{47}$ as well as issues such applications of the FCA have raised, many of which arise in the context of IRBs. Part III will address the resolution of those issues in that context.

42 Associated Press, Report on a Research Death at A16 (cited in note 39).

43 Grimes v Kennedy Krieger Institute, Inc, 366 Md 29, 782 A2d 807, 858 (Md App 2001) (holding that a legal guardian "cannot consent to the participation of a child or other person under legal disability in nontherapeutic research or studies in which there is any risk of injury or damage to the health of the subject").

44 Id at 812.

45 Id at 813-14.

46 Tamar Lewin, US Investigating Johns Hopkins Study of Lead Paint Hazard, NY Times A11 (Aug 24, 2001). If the research does not present the prospect of direct benefit to the child, the Federal Regulations require the IRB to make additional findings, and limit the risk to the subjects. Compare 45 CFR $\$ 46.405$ and $\S 46.406$.

47 Although there are many fraud and abuse laws other than the FCA that are often applied in the healthcare context, this Comment will focus on the Anti-Kickback law, 42 USC $\S 1320 \mathrm{a}-7 \mathrm{~b}(\mathrm{~b})(1)(B)(1994)$, and the Ethics in Patient Referrals Act (the "Stark law"), 42 USC $\S 1395 \mathrm{nn}$ (1994), in particular. 


\section{A. Overview of the FCA}

1. What constitutes a fraudulent claim.

The FCA was passed in 1863 to combat rampant fraud in civil war defense contracts. ${ }^{48}$ It provides for civil damages against any person who "knowingly makes, uses, or causes to be made or used, a false record or statement to get a false or fraudulent claim paid or approved by the Government." ${ }^{49}$ These damages are measured at three times the amount of the false claim (or two times the amount if the defendant cooperates with the government) plus not less than $\$ 5,000$ and not more than $\$ 10,000$ per false claim submitted. ${ }^{30}$ Finally, in addition to a suit brought by the government, ${ }^{\text {st }}$ a private citizen, or relator, can bring a qui tam action on behalf of the federal government. ${ }^{52} \mathrm{Gen}-$ erally, the relator is entitled to $15-25$ percent of the damages if the government intervenes ${ }^{33}$ and $25-30$ percent of the damages if the government does not. ${ }^{\text {st }}$

When alleging a violation of the FCA, the prosecutor or relator must show that (1) the defendant submitted or caused to be submitted a claim for payment to the federal government; (2) the claim was false or fraudulent; and (3) the defendant knew or should have known that the claim was false. In addition, some courts require that the government suffer pecuniary loss as a result of the claim, although this criterion is not universally required. ${ }^{\text {s6 }}$

\section{Scienter.}

In order to bring a qui tam action, the relator must show that the defendant knew or should have known that he was submitting a false claim or making a false statement in support of a claim being filed with the federal government. ${ }^{57}$ It is important to note, however, that no intent actually to defraud the government is required; the scienter re-

48 False Claims Amendment Act of 1986, S Rep No 99-345, 99th Cong, 2d Sess (1986), reprinted in 1986 USCCAN 5266-5303.

4931 USC $\$ 3729(\mathrm{a})(2)$. The FCA also provides for other causes of action. For present purposes, the other relevant subsection is 31 USC $\$ 3729$ (a)(1) (providing that "anyone who knowingly presents, or causes to be presented, to an officer or employee of the United States Government ... a false or fraudulent claim for payment or approval" is liable to the government).

so 31 USC $\$ 3729(a)(7)$.

5131 USC $\$ 3730$ (a) (Supp 2001).

5231 USC $\$ 3730(\mathrm{~b})$.

5331 USC $\S 3730(d)(1)$.

5431 USC $\$ 3730(d)(2)$.

5531 USC \$ 3729(b); John T. Boese, Civil False Claims and Qui Tam Actions, § 2.01[A] at 2-8 (Aspen 2d ed 2001).

56 Pogue v American Healthcorp, Inc, 914 F Supp 1507, 1508-09 (M D Tenn 1996) (“Pogue

$\left.\Gamma^{\prime \prime}\right)$ (noting the conflict between courts on the issues of actual damages).

5731 USC $\$ 3729(a)(1)$. 
quirement only applies to whether the information given to the government is false.

In addition, the statute was amended in 1986 to clarify the definition of "knowingly" to include not only actual knowledge but also claims filed in deliberate ignorance or with reckless disregard of the truth or falsity of the information. ${ }^{59}$ Thus, an individual cannot use the so-called "ostrich" defense and must "make a reasonable and prudent" inquiry to ensure the claim is accurate. ${ }^{60}$ What this includes, however, is unclear on the face of the statute, and subsequent case law has not made that standard any clearer. The seminal case on the matter is United States $v$ Krizek, ${ }^{61}$ in which the government challenged the defendant psychiatrist's billing practices. ${ }^{62}$ The court noted that the billing practice lacked any centralization or control, so that in many instances duplicate bills were submitted, many of the bills had little or no factual support, and the psychiatrist frequently failed to review the claims submitted by his wife on his behalf ${ }^{63}$ As a result, even though there was no evidence that the defendant knowingly submitted false claims, the court upheld a finding that the defendant was reckless and therefore liable under the Act. . $^{4}$ As in this case, courts commonly find recklessness when the defendant did not have a sufficient factual basis to support the claim and when a proper investigation was not performed, ${ }^{\circ 5}$ as well as in instances in which the individual misunderstood the relevant regulations but the court finds that he should have understood them. ${ }^{6}$

\section{Measure of damages.}

Courts are split as to whether the relator or prosecution must show that the government actually suffered pecuniary damages to bring a suit under the FCA. The statute provides a penalty of "three

5831 USC \& 3729(b). See, for example, Peterson $v$ Weinberger, 508 F2d 45, 54 (5th Cir 1975) (holding a doctor liable for depositing Medicare reimbursements for claims that he did not file); United States $v$ Aerodex, Inc, 469 F2d 1003, 1008 (5th Cir 1973) (allowing a suit against a defendant who relabeled 300 master rod bearings to fill a government order even though the substituted bearings were interchangeable with those specified by the contract).

59 31 USC $\$ 3729$ (b).

60 S Rep No 99-345 at 5285-86 (cited in note 48).

61111 F3d 934 (DC Cir 1997).

62 Id at 935.

63 Id at 942.

64 Id.

65 See, for example, United States $v$ Raymond \& Whitecomb Co, 53 F Supp 2d 436, 446 (S D NY 1999) (noting that failure to investigate can be enough to prove recklessness).

66 United States v Mackby, 261 F3d 821, 828 (9th Cir 2001) ("Participants in the Medicare program have a duty to familiarize themselves with the legal requirements for payment.").

67 Harrison v Westinghouse Savannah River Co, 176 F3d 776, 785 n 7 (4th Cir 1999) (noting the conflict among courts on the issue of actual damages); Pogue I,914 F Supp at 1508-09. 
times the amount of damages which the Government sustains because of the act" of the defendant." This has led some to argue that actual damages are required in order to bring suit under the FCA. Nevertheless, in 1956 the Supreme Court held in Rex Trailer Co, Inc v United States that "there is no requirement, statutory or judicial, that specific damages be shown." ${ }^{, 69}$ The Court noted, however, that the government suffered an injury, even if it was impossible to quantify. ${ }^{70}$ Courts have subsequently held that "damages" must not be limited to a net loss to the government; for instance, courts have found that paying a claim sooner than it was rightfully due ${ }^{71}$ and paying a claim to an improper

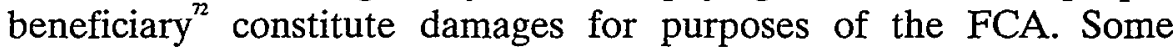
courts, however, in seeming contradiction to Rex Trailer, have held that the plaintiff must show damages in order to recover under the FCA. ${ }^{73}$ Nevertheless, the clear weight of authority suggests that the defendant does not have to show actual damages to the government.

6831 USC \$ 3729(a) (Supp 2001).

69350 US $148,152(1956)$.

70 Id at 153 ("It is obvious that injury to the Government resulted from the Rex Trailer Company's fraudulent purchase of trucks. It precluded bona fide sales to veterans, decreased the number of motor vehicles available to Government agencies, and tended to promote undesirable speculation.").

71 Young-Montenay, Inc v United States, 15 F3d 1040, 1043 (Fed Cir 1994). Although the defendant in that case argued that the only damages that should have been allowed were the interest payments the government could have received if it had paid the claim at the proper time, the court found the defendant liable for the entire amount of the false claim. Id at $1043 \mathrm{n} 3$.

72 See, for example, Peterson, 508 F2d at 52-54 (holding a physician liable under the FCA for submitting claims for services that were in actuality performed by his brother's physical therapy corporation).

73 Wilkins v Ohio, 885 F Supp 1055, 1060 (S D Ohio 1995) (“[W]hile § 3729(a) authorizes recovery of any damages sustained by the United States upon proof of those damages by the plaintiff, no damages need be proved in order to recover the civil penalty of $\$ 5,000$ specified in that section."); Stinson, Lyons, Gerlin \& Bustamonte, PA v Provident Life \& Accident Insurance Co, 721 F Supp 1247, 1258-59 (S D Fla 1989) (stating that the FCA requires that the government suffer damages as a result of the submission of a false or fraudulent claim); Blusal Meats, Inc $v$ United States, 638 F Supp 824, 827 (S D NY 1986) (noting that a statutory fine was available if the government could not prove damages).

74 See, for example. Hagood v Sonoma Co Water Agency, 929 F2d 1416, 1421 (9th Cir 1991) ("A civil penalty of between $\$ 5,000$ and $\$ 10,000$, and the costs of the civil action, are also recoverable under the statute, 31 USC $\$ 3729$ (a). No damages need be shown in order to recover the penalty."); Pogue I, 914 F Supp at 1508-09 ("While there is clearly some disagreement among the courts regarding this issue, this Court cannot ignore the decision of the Supreme Court in Rex Trailer."); United States v Kensington Hospital, 760 F Supp 1120, 1127 (E D Pa 1991) ("Controlling Supreme Court and Third Circuit precedents hold that the government need not show actual damage in order to prove a violation of the False Claims Act."). See also James B. Helmer, Jr., Paul B. Martins, and Julie W. Popham, Recovery of Damages under the False Claims Act, N98CFCB, ABA Center for Continuing Legal Education C-2-C-3 (Nov 19-20, 1998) (noting that "overwhelming authority holds that a viable False Claims Act action may exist without proof of actual damages"). 


\section{Jurisdictional issues.}

In many actions brought under the qui tam provisions of the FCA, the court must also determine whether the relator is relying on publicly disclosed information to bring the suit. ${ }^{75}$ If it concludes that the information upon which the relator is basing his action was publicly available, the court loses jurisdiction over the action. ${ }^{76}$ The rationale for this requirement is clear: the government allows qui tam suits to be brought because insiders generally have more information about fraudulent claims than a prosecutor would. ${ }^{n}$ If, however, the information is publicly available, the government does not need the relator to bring the suit, since it could bring it on its own and recover the full amount of the loss.

a) Information must be publicly available. It is unclear what standard of information is sufficient to deprive a court of jurisdiction over a qui tam suit. Courts generally note a difference between the disclosure of mere information and the disclosure of "allegations or transactions." "What constitutes an allegation or transaction, however, is not well defined. Generally, to find that they lack jurisdiction, courts require that either the allegation of fraud itself or all of the critical elements of the fraud must be contained in the public materials." For example, in Pogue $v$ American Healthcorp, Inc ("Pogue II") the court ruled that while the information that formed the basis of the claim was gathered from documents filed with the SEC, newspaper reports, and other publicly available sources, ${ }^{\mathrm{s}}$ there was insufficient information in these sources to deprive the court of subject matter jurisdiction." Even though the defendant argued that the facts necessary to show that the Anti-Kickback law ${ }^{82}$ was violated could reasonably be

7531 USC $\$ 3730(\mathrm{e})(4)$ (A) (1994).

76 Id (denying jurisdiction to a qui tam claim "based upon the public disclosure of allegations or transactions in a criminal, civil, or administrative hearing, in a congressional, administrative, or Government Accounting Office report, hearing, audit, or investigation, or from the news media, unless the ... person bringing the action is an original source of the information").

77 Springfield Terminal Railway Co v Quinn, 14 F3d 645, 649-51 (DC Cir 1994) (discussing the rationale behind allowing qui tam actions).

78 See, for example, Wang v FMC Corp, 975 F2d 1412, 1418 (9th Cir 1992) ("Courts sometimes speak loosely of barring a qui tam suit because it is based on 'publicly disclosed information' .... But the Act bars suits based on publicly disclosed 'allegations or transactions,' not information.") (citations omitted).

79 Springfield Terminal, 14 F3d at 654 (stating that the court believes that Congress, by its careful choice of terminology in the 1986 amendments, created "a standard under which qui tam actions are barred only when enough information exists in the public domain to expose the fraudulent transaction ... or the allegation of fraud," since if either is true, the government does not need the relator in order to bring suit).

80 977 F Supp 1329, 1335-37 (M D Tenn 1997).

81 Id at 1338-39.

82 See text accompanying notes 90-92. 
inferred from the available information, the court nevertheless allowed the action to proceed. ${ }^{8}$

b) The original source exception. Although courts are ordinarily deprived of subject matter jurisdiction over a claim that is based on publicly available information, the FCA makes an exception for instances in which the relator is an "original source of the information."." An original source is defined as "an individual who has direct and independent knowledge of the information on which the allegations are based and has voluntarily provided the information to the Government before filing an action under this section which is based on information." ${ }^{\star s}$ Thus, when an individual provides information to the government, but the government does not subsequently bring suit, the individual is not barred from doing so herself even though the government possesses the information. To bring suit, the putative relator must have direct and independent knowledge of the information, a requirement that would not be satisfied "where one would not have learned of the information but for its public disclosure."

\section{B. Application of the FCA to Fraud and Abuse Laws}

The reach of the FCA is nowhere more striking than in the recent decisions using violations of health care fraud and abuse laws as the basis for qui tam actions." In addition to bringing suit under the myriad of regulations governing Medicare and Medicaid, individuals and the government have brought suit under two laws: the Anti-Kickback law and the Stark law.

83 Pogue II, 977 F Supp at 1339-40. See also Cooper v Blue Cross and Blue Shield of Florida, Inc, 19 F3d 562, 567 (11th Cir 1994) (per curiam) (concluding that a GAO report criticizing defendant for a failure to monitor payments, possibly implicating a conflict of interest, was not sufficient to raise the jurisdictional bar since the report did not actually allege that the defendant was guilty of any wrongdoing); Schwedt $v$ Planning Research Corp, Inc, 39 F Supp 2d 28, 33 (D DC 1999) (holding that the public disclosure of errors and incompleteness in delivery to the government was sufficient to deprive the court of jurisdiction). For a general discussion, see Robert Salcido, Screening out Unworthy Whistleblower Actions: An Historical Analysis of the Public Disclosure Jurisdictional Bar to Qui Tam Actions under the False Claims Act, 24 Pub Con L J 237 (1995) (concluding that courts originally construed the bar too narrowly, but that now they construe it properly).

8431 USC $\$ 3730(\mathrm{e})(4)(\mathrm{A})$.

8531 USC $\$ 3730(\mathrm{e})(4)(\mathrm{B})$.

86 Wang, 975 F2d at 1417, citing Houck v Folding Carton Administration Committee, 881 F2d 494, 505 (7th Cir 1989).

87 See generally Robert N. Rabecs, Kickbacks as False Claims: The Use of the Civil False Claims Act to Prosecute Violations of the Federal Health Care Program's Anti-Kickback Statute, 2001 Detroit Coll L Rev 1, 4 (noting that the use of the FCA to prosecute violations of the antikickback statute "greatly expands the application and scope of the False Claims Act").

88 See, for example, Mikes v Straus, 274 F3d 687, 693 (2d Cir 2001) (noting plaintiff's claim that defendants' receipt of referral fees from Medicare for referrals to facilities in which defendants held a financial interest violated the anti-kickback provision of the Medicare statute, 42 USC § 1320a-7b(b)(1) (1994)). 
The Anti-Kickback law holds criminally liable any individual who pays money to induce another individual to purchase, lease, or recommend the purchase of any service under Medicare or Medicaid." The goal of the law is to prevent hospitals or other organizations from inducing physicians to give additional referrals to such an entity." To prove a violation of the Anti-Kickback law, the government must show (a) the requisite scienter (knowingly or willingly), (b) solicitation or remuneration, and (c) that such solicitation or remuneration was aimed at inducing referrals.

The Stark law prevents physicians who have a financial interest in a specified list of entities (for example, a laboratory) from making referrals to that entity (for example, for a blood test). ${ }^{3.3}$ This law was enacted to protect against over-referrals by physicians to their own laboratories for personal profit. "Unlike the Anti-Kickback law, the Stark law is a strict liability statute and only applies to Medicare claims submitted to the government.

\section{Violation of fraud and abuse laws as a per se violation of the FCA.}

Since neither the Anti-Kickback law nor the Stark law provides for a private right of action, ${ }^{\text {, }}$ many citizens have brought qui tam actions under the FCA. Citizens bringing such actions have argued that

89 Thompson v Columbia/HCA Healthcare Corp, 125 F3d 899, 902 (5th Cir 1997) (recognizing that the submission of a false certification of compliance with the Stark law can constitute a false claim under the FCA); Gublo v NovaCare, Inc, 62 F Supp 2d 347, 355 (D Mass 1999) (noting that if payment of Medicaid or Medicare claims for services rendered was conditioned on defendant's false certifications and violations of the Stark law, then plaintiffs properly allege a violation of the FCA).

so 42 USC $\S 1320 \mathrm{a}-7 \mathrm{~b}(\mathrm{~b})(1)(B)$.

91 See 42 CFR $\S 1001$ (2001). Certain transactions are exempted. See 42 CFR $\S 1001.952$.

92 Hanlester Network v Shalala, 51 F3d 1390, 1398-1401 (9th Cir 1995).

93 The relevant text of the law provides that if a physician or an immediate family member has a financial relationship to a specified entity,

(A) the physician may not make a referral to the entity for the furnishing of designated health services for which payment otherwise may be made under this subchapter, and (B) the entity may not present or cause to be presented a claim under this subchapter or bill to any individual, third party payor, or other entity for designated health services furnished pursuant to [such a prohibited referral].

42 USC $\$ 1395 n n(a)(1)(A)-(B)$.

94 See Clark C. Havighurst, James F. Blumstein, and Troyen A. Brennan, Health Care Law and Policy 485-86 (Fountain 2d ed 1998).

9542 USC $\S 1395 \mathrm{nn}(\mathrm{a})(1)$. See also Anne W. Morrison, An Analysis of Anti-Kickback and Self-Referral Law in Modern Health Care, 21 J Leg Med 351, 375 (2000) (contrasting the liability standards of the Anti-Kickback and Stark laws).

96 West Allis Memorial Hospital, Inc v Bowen, 852 F2d 251, 255 (7th Cir 1988) (holding that the Stark law does not provide a private right of action); Donovan v Rothman, $106 \mathrm{~F}$ Supp 2d 513,516 (S D NY 2000) (finding that there is no private cause of action to redress violations of the anti-kickback statute); Roy v Anthony, 914 F Supp 1504, 1506 (S D Ohio 1994) (same). 
since physicians must meet the requirements of the Anti-Kickback and Stark laws in order to submit a claim for reimbursement under Medicare, any claim for services rendered in violation of these laws is fraudulent. Courts have generally been receptive to those arguments." While courts are generally quick to point out that "violations of laws, rules, or regulations alone do not create a cause of action under the FCA, ${ }^{\text {"sg }}$ those same courts will generally allow such an action to be brought in the case of the Anti-Kickback and Stark laws. ${ }^{9}$ Presumably then, these same courts would permit a claim premised on the violation of federal regulations governing human subjects research.

\section{Establishing the falsity or fraudulent nature of a claim: implied certification.}

While the government would not ordinarily pay for a claim submitted in violation of fraud and abuse laws, it is often uncertain whether a particular claim indicates that the individual had complied with the applicable regulations. If it does not, some have argued, the claim itself is not false and should not be actionable under the FCA. This is not to say that the individual should not be punished-fraud and abuse statutes themselves provide for stiff penalties ${ }^{100}-$ but rather that the FCA is not the method by which those statutes should be enforced.

In response to this argument, some courts have not required an express statement that the individual requesting funding has complied with applicable federal regulations. Beginning with $\mathrm{Ab}$-Tech Construction, Inc v United States, ${ }^{\mathrm{g} 1}$ these courts have held that a submission

97 See, for example, Pogue I, 914 F Supp at 1509-13 (giving an extended discussion of all FCA claims brought to date based on the Anti-Kickback and Stark laws, and concluding that the prevailing view is that a violation of either may constitute a violation of the FCA).

98 Hopper $v$ Anton, 91 F3d 1261, 1266 (9th Cir 1996) (holding that a school district's general assurances that it would comply with applicable federal law pertaining to special education programs did not support a claim under the FCA).

99 Thompson v Columbia/HCA Healthcare Corp, 125 F3d at 902 (stating that where the government's payment of Medicare claims is conditioned on compliance with the anti-kickback statute and the Stark law, plaintiffs correctly-allege a violation of the FCA). See also Gublo v Novacare, Inc, 62 F Supp 2d 347, 355 (D Mass 1999) (holding that "if payment of Novacare's Medicare or Medicaid claims ... was conditioned on Novacare's false certifications. . then plaintiffs properly allege a violation of the FCA"). But see Roy, 914 F Supp at 1506 (describing the connection between violations of the FCA and the fraud and abuse laws as a "tenuous" one, but still allowing the suit to survive the summary judgment stage).

10042 USC $\$ 1320 \mathrm{a}-7 \mathrm{~b}(\mathrm{~b})(1)$ (imposing penalties of up to $\$ 25,000$ and five years imprisonment for violating the anti-kickback provisions); 42 USC $\$ 1395 \mathrm{nn}(\mathrm{g})(3)-(4)$ (imposing fines of $\$ 15,000$ per claim submitted in violation of the Stark law and imposing a $\$ 100,000$ fine for schemes to evade the Stark law).

10131 Fed Cl 429, 433-34 (1994) (finding that the submission of progress payment vouchers, which represented an implied certification of $\mathrm{Ab}$-Tech's continued adherence to federal requirements, constituted false claims under the FCA). 
creates an "implied certification" that the claim meets the requirements of all federal laws and regulations. ${ }^{102}$ Courts imply that the defendant has complied with the requisite health care laws and regulations from the submission of a claim, since as a matter of law the defendant should have complied with them in order to receive funding. ${ }^{100}$

There is a significant amount of disagreement over the implied certification theory, ${ }^{104}$ with many courts rejecting the theory altogether. ${ }^{105}$ Especially in the context of the Anti-Kickback and Stark laws, mere technical violations of rather lengthy statutory requirements could lead to liability based on implied certification. ${ }^{106}$ Furthermore, commentators argue that violation of a health care regulation does not necessitate the government's refusal to pay the particular claim and that therefore the claim is not false. ${ }^{100}$ Under the AntiKickback law, HHS has some discretion about whether to terminate funding after a regulatory violation is discovered, ${ }^{108}$ and often overlooks such a violation. ${ }^{109}$ Even now the government may choose to ex-

$10231 \mathrm{Fed} \mathrm{Cl}$ at 434. See also Shaw $v$ AAA Engineering \& Drafting, Inc, $213 \mathrm{F3d} 519,531-33$ (10th Cir 2000) (permitting FCA liability based on implied certification in the submission of monthly invoices).

103 Pogue I, 914 F Supp at 1509, 1513 (finding plaintiff's implied certification argument sufficient to survive a motion for summary judgment). See also Robert Fabrikant and Glenn E. Solomon, Application of the Federal False Claims Act to Regulatory Compliance Issues in the Health Care Industry, 51 Ala L Rev 105, 148 (1999) ("The false certification cases ... rest on the proposition that the provider ... certified in its claims for reimbursement that it had provided the care at issue in a manner consistent with the prevailing standards of care.").

104 See, for example, Fabrikant and Solomon, 51 Ala L Rev at 149-56 (cited in note 103) (arguing against the use of the implied certification doctrine in the healthcare context); Rabecs, 2001 Detroit Coll L Rev at 63-68 (cited in note 87) (discussing FCA liability based on "implied certifications" of compliance with the anti-kickback statute when medicare reimbursement forms do not require express certifications with this statute).

105 Joslin v Community Home Health of Maryland, Inc, 984 F Supp 374, 384 (D Md 1997) ("To hold that the mere submission of a claim for payment, without more, always constitutes an 'implied certification' of compliance with the conditions of the Government program seriously undermines [the theory of the FCA].").

106 Fabrikant and Solomon, 51 Ala L Rev at 151 (cited in note103) ("[T]he healthcare industry is so heavily regulated that providers and suppliers neither know nor understand, and cannot reasonably be expected to know and understand, all of the laws and regulations that govem their operations.").

107 John T. Boese and Beth C. McClain, Why Thompson Is Wrong: Misuse of the False Claims Act to Enforce the Anti-Kickback Act, 51 Ala L Rev 1, 46 (1999) (arguing that because the government has discretion in enforcing the anti-kickback statute, a violation may not result in an obligation to repay the government and hence is not actionable under the FCA).

103 HHS must now exclude those convicted of committing felonies relating to financial misconduct after August 21, 1996. See 42 USC $\S 1320 a-7(a)(3)$ (1994). Nevertheless, FCA claims were brought before the 1996 amendment when enforcement under the Anti-Kickback law was still discretionary.

109 Boese and McClain, 51 Ala L Rev at 43 (cited in note 107):

[T] De DHHS has excluded hundreds, perhaps thousands, of healthcare providers for violations of the AKA. In no published case, however, has the DHHS or the DOJ ever filed an FCA case seeking FCA damages amounting to retroactive recovery of all the federal funds 
empt a practice that may be a technical violation of the law. ${ }^{110}$ If the government would have been willing to pay the claim despite the regulatory violation, it is difficult to see how the purpose of the FCA would be furthered by allowing the suit."

In response to these concerns, some courts have limited the $A b$ Tech implied certification theory of liability to instances in which the regulatory violation is at the heart of the certification, ${ }^{12}$ or in which compliance with regulations or other legal provisions is expressly required as a precondition for payment. ${ }^{113}$ In both cases, the limitation is based on the premise that the FCA only covers cases in which the government would have changed its decision to pay the particular claim if it possessed the information revealed in the suit. This standard parallels the principle that mere technical violations of regulations do not make a claim false for purposes of the FCA. ${ }^{114}$ For instance, in Luckey $v$ Baxter Healthcare Corporation, ${ }^{115}$ the court concluded that even though the defendant was required to meet regulations prescribing the standard of care for laboratory work, compliance with these regulations was not material to receiving payment from the government and hence noncompliance was not actionable. ${ }^{116}$

Similarly, in Mikes $v$ Straus, ${ }^{117}$ the court held that implied certification applied to a statute that required the amount of a Medicare payment to include only services that were reasonable and necessary, since the statute explicitly stated that a service not meeting this standard was not eligible for payment. ${ }^{118}$ On the other hand, the court refused to allow an additional claim based on an implied certification

that were paid to the newly-excluded provider.

Enforcement of the Stark law is not discretionary. See 42 USC $\$ 1395 n n(g)(1)$ (providing that no payment shall be made for a designated health service provided in violation of the Stark law).

110 Dayna B. Matthew, Tainted Prosecution of Tainted Claims: The Law, Economics, and Ethics of Fighting Medical Fraud under the Civil False Claims Act, 76 Ind L J 525, 540 (2001).

111 The purpose of the FCA is to "protect the federal treasury." Pogue I, 914 F Supp at 1513. For a general discussion, see $S$ Rep No 99-345 (cited in note 48).

112 Luckey v Baxter Healthcare Corp, 2 F Supp 2d 1034, 1044-45 (N D Ill 1998) (declining to find that Baxter breached an implied certification in part because "unlike $A b$-Tech, there is no evidence that Baxter's practice violated the heart of its agreement with the government").

113 Siewick v Jamieson Science and Engineering, Inc, 214 F3d 1372, 1376 (DC Cir 2000) ("Courts have been ready to infer certification from silence, but only where certification was a prerequisite to the government action sought.").

114 Lamers $v$ City of Green Bay, 168 F3d 1013, 1019 (7th Cir 1999) (stating that public confusion caused by new bus routes and city's trouble providing clear maps were minor technical violations normal for a new bus program and did not give rise to an FCA claim).

1152 F Supp 2d 1034, 1034 (N D Ill 1998).

116 Id at 1044-45. See also Thompson, 125 F3d at 902-03 (rejecting the implied certification theory, but allowing the suit to continue on the theory that there was an express certification of compliance with the applicable regulations).

117274 F3d 687 (2d Cir 2001).

118 Id at 700-01, discussing 42 USC $\$ 1395 y(a)(1)(A)(1994)$. 
theory under a different statute that required a physician to assure that his services would meet the required standard of care in order to be eligible for funding. ${ }^{119}$ Noting that this latter requirement was a prospective requirement for participation in Medicare rather than a precondition of payment, and noting that violation of this section did not mandate nonpayment of the claim, the court held that there was no implied certification with respect to this section. ${ }^{120}$

\section{Scienter requirements.}

Interestingly, many courts have failed to address the FCA's scienter requirement when discussing violations of the fraud and abuse laws. This is not a problem for suits alleging violations of the AntiKickback law, since to establish such a violation the defendant must have acted with the same level of intent required by the FCA. There is no scienter requirement, however, for violations of the Stark law. Thus, to allow a violation of the Stark law to constitute a per se violation of the FCA would essentially be to ignore the scienter requirement of the FCA.

Furthermore, it is not clear that an individual who submits a claim in violation of the fraud and abuse laws would know that his claim is false if he is unaware of the existence of those laws, calling into question the implied certification doctrine. While ignorance is not a defense for violations of the fraud and abuse statutes themselves, it might be a defense for violation of the FCA. ${ }^{12}$ The court might alternatively conclude that ignorance of the fraud and abuse laws themselves, or the belief that one was in compliance with them, was reckless and therefore actionable under the FCA. This is unlikely, however, given the complex nature of the laws. ${ }^{123}$

119 Mikes, 274 F3d at 701-02 (discussing the plaintiff's reliance on 42 USC $\$ 1320 \mathrm{c}-5$ (a) (1994)). See also Fabrikant and Solomon, 51 Ala L Rev at 122-24 (cited in note 103) (distinguishing between conditions of participation and conditions of payment).

120 Mikes, 274 F3d at 701.

121 See, for example, Joslin, 984 F Supp at 384 (registering concern with an interpretation of the FCA that would allow a plaintiff to show that the individual did not meet regulatory requirements without showing the requisite scienter).

122 Id at 384-85 ("While ignorance of the law is usually no excuse to justify one's actions, the FCA requires that a false statement be made with actual knowledge, deliberate ignorance, or reckless disregard of the statement's falsity.").

123 Robert Salcido, The Government Unleashes the Stark Law to Enforce the False Claims Act: The Implications of the Government's Theory for the Future of False Claims Act Enforcement, 13 Health Lawyer 1, 3 (Aug 2001) (noting that the Stark law is "so vague that it require[d] several rounds of rulemaking spanning more than a half dozen years and yet the government still has not arrived at a definitive conclusion regarding the proper scope and interpretation of the statute," and arguing that it is unfair to charge defendants with "knowing and understanding the full scope of the statute such that they are subjected to treble damages and civil penalties for breaching the Act's undefined terms"). 


\section{THE APPLICATION OF THE FCA TO SUITS AGAINST IRBS}

Until now, only two suits have been brought by the government alleging violation of the FCA with respect to federally funded human subjects research. ${ }^{124}$ This is not surprising, given the paucity of claims against IRBs and universities with respect to human subjects research in general. Furthermore, in the majority of the few cases that have been brought, plaintiffs have generally relied on the tort system to provide a remedy. This Part argues that the FCA may allow a preferable cause of action in certain cases. Using the cases discussed in Part I as illustrations, this Part also discusses how courts should analyze the FCA cause of action and resolves some of the issues raised in Part II. This Part will show that a suit under the FCA alleging violations of the Common Rule will only be successful if three conditions are met: (1) the government, specifically OHRP, is not aware of the violations; (2) the violations are substantive, material to the government's decision to fund, and not merely technical; and (3) the IRB knew that the research violated the federal regulations or was reckless in applying them, in effect "rubber stamping" the research protocol.

\section{A. The FCA Provides an Attractive Cause of Action against an IRB}

While a tort suit against an IRB alleging negligence in the fulfillment of its duties would be attractive in many cases, there are instances in which a tort suit would not be viable and in which the FCA may provide for higher damages. First, the plaintiff need not have suffered personal injury in a suit brought under the FCA; all that is required is the submission of a false claim. Thus, in instances where it would be difficult to prove causation or that the plaintiff suffered damages (both requirements of a typical tort suit), the FCA may provide the only way for a plaintiff to sue. For instance, as in the Robertson case, the plaintiff may not have suffered any physical injury, ${ }^{125}$ so it would be unclear how the improper oversight by the IRBs injured the plaintiff and whether a tort suit would lie. In that case, however, assuming that the actions uncovered by OHRP are true, the IRB should face some repercussions. While sanctions normally are issued by OHRP, this is not always the case, especially in instances where there is no injury to capture OHRP's attention.

124 Zissler $v$ Regents of the University of Minnesota, 154 F3d 870, 875 (8th Cir 1998) (finding states to be "persons" under the liability provisions of the FCA and remanding for proceedings on the plaintiff's claim of misuse of federal funds in an organ transplant research program); Chandler v Hektoen Institute for Medical Research, 35 F Supp 2d 1078, 1080 (N D Ill 1999) (denying the defendant's motion to dismiss a claim filed under the FCA for misconduct in implementing a federally funded study of drug-dependent pregnant women). See text accompanying notes 32-37.

125 See note 38 and text accompanying notes 33-38. 
Furthermore, the FCA could allow a plaintiff who was not even involved in the research to sue on behalf of the federal government. Again considering the Robertson case, the nurse who uncovered the negligence on the part of the IRB would not be able to sue under the tort system because she was not harmed by the IRB's allegedly poor oversight. She could, however, sue under the FCA. Thus, the FCA suit against the IRB has unique benefits because it is in society's interest to encourage the nurse to come forward with information. This encouragement is exactly the goal of the qui tam provisions of the FCA.

The award under the FCA might also be greater than that given by the tort system. First, the damages can be trebled in certain circumstances. ${ }^{125}$ More importantly, the defendant is also liable for between $\$ 5,000$ and $\$ 10,000$ per false claim filed. ${ }^{127}$ If a relator were to identify a systematic violation of the federal regulations by an IRB that resulted in many false claims being filed, the relator could stand to receive a generous award even when limited to his statutory share of 30 percent. $^{128}$

\section{B. The Policy Implications of Suits against IRBs Are Mixed}

While a suit under the FCA may have benefits over a tort suit for a litigant, several commentators have questioned the wisdom of allowing suits against an IRB. Most have expressed concern that allowing IRB members to be held liable would make their participation on the IRB less likely. ${ }^{129}$ This concern, however, is mitigated because the research institution sponsoring the research, or the researcher himself, could always indemnify IRB members in the event they are sued under the FCA. ${ }^{130}$ Furthermore, it would seem in the interests of the institution to provide indemnification to assure the existence of an IRB,

12631 USC \& 3729(a).

127 Id.

128 Rabecs, 2001 Detroit Coll L Rev at $29 \& \mathrm{n} 72$ (cited in note 87) (noting that the civil penalties imposed by the FCA can be disproportionate to the actual damages suffered by the government); Boese and McClain, 51 Ala L Rev at 19 (cited in note 107) (discussing the possibility that an extra charge of $\$ 1.00$ for a laboratory test would only generate $\$ 1,000$ in damage to the government if there were 1,000 such tests, but that the civil penalties could be as high as $\$ 10$ million).

129 Anderlink and Elster, $29 \mathrm{~J} \mathrm{~L} \mathrm{Med} \mathrm{\&} \mathrm{Ethics} \mathrm{at} 225$ (cited in note 5) ("Given our experience with IRBs, we believe that the prospect of being hauled into court whenever a clinical trial goes badly will likely discourage those who are most qualified (typically those who have the most to lose) from participating on an IRB."); National Commission for the Protection of $\mathrm{Hu}$ man Subjects of Biomedical and Behavioral Research, Report and Recommendations: Institutional Review Boards 85, DHEW Pub No (OS) 78-008 (GPO 1978) ("[S]ome people may not serve on an IRB if they know that they risk suit.").

130 See, for example, Ruth Scheuer, Research in the Hospital Setting on Human Subjects: Protecting the Patient and the Institution, 60 Mt Sinai J of Med 391, 393 (1993) (suggesting that research institutions require the researcher to indemnify the institution and its employees as a condition of conducting research at the institution). 
since IRBs are the only vehicle through which it can receive government funding for research involving human subjects.

The other problem with allowing FCA suits is overdeterrence. IRBs, fearful of a lawsuit, might be too cautious in approving research and withhold authorization for valuable research that does, in fact, comply with the federal regulations. Overdeterrence could result regardless of whether the institution indemnified the members of the IRB; faced with FCA or negligence claims, the institution may pressure the IRB to be more meticulous in its approval of research. The problem of overdeterrence is compounded because IRBs are already overburdened with the amount of research they must approve. ${ }^{131}$ Any increase in the amount of time spent approving research would come at the expense of approving fewer research protocols or requiring the creation of additional IRBs, raising the costs of the human subjects protection system. The potential costs are also increased because, as previously noted, ${ }^{132}$ damages may be trebled and the IRB could be liable for $\$ 5,000-\$ 10,000$ per claim filed. These costs could put additional strain on the system and would, especially in the case of medical drugs and devices, ultimately be passed on to the consumer.

These added costs, however, must be weighed against the benefit of allowing such suits. While trivial suits that do not affect the protection afforded human subjects research would not be sufficiently beneficial to outweigh the costs to the system, it is conceivable that suits under the FCA might improve human subjects protection in ways the tort system cannot. For instance, while the tort system only addresses failures of the system that harm an individual, FCA suits could reach instances in which the protections were inadequate but did not result in physical harm. This is important for two reasons. First, OHRP is unlikely to be cognizant of such lapses. With limited resources, OHRP rarely conducts investigations of IRBs, ${ }^{133}$ and is likely to do so only if it has reason to suspect problems with the institution's human subject protections. Generally, OHRP only becomes aware of these lapses when a human subject has been injured and the injury is reported by the media. By allowing a suit under the FCA, a plaintiff could bring the alleged problems to OHRP's attention or allow for an alternative means of sanctioning an ill-functioning IRB. While an individual might contact OHRP in the absence of the FCA, as the nurse in the Robert-

131 George Grob, Deputy Inspector General for Evaluation and Inspection, HHS, Institutional Review Boards: A System in Jeopardy, statement before the Subcommittee on Human Resources of the House Committee on Government Reform and Oversight (1998) (noting a 42 percent increase in research protocols approved by an IRB over a five-year period).

132 See text accompanying notes $126-28$.

133 OHRP, Protecting Human Research Subjects, 2, OEI-01-97-00197 at 2 (Apr 2000) (noting that between June 1998 and March 2000, OHRP only conducted ten on-site investigations). 
son case did, many employees (who like the nurse would be in the best position to know of violations of the federal regulations) might be afraid to come forward for fear of reprisal..$^{134}$ Finally, society should want the problem with IRBs to be reported and corrected before an injury; the legal system should not wait until after a fatality to fix the problem.

As a matter of policy, then, FCA claims should be encouraged insofar as they affect substantive provisions of the human subjects protection system. Those lapses that are more likely to go unnoticed are particularly attractive candidates for an FCA suit. Finally, there should be some balance between the desire to use monetary damages as an incentive to follow the regulations on one hand and the desire to minimize additional costs to the system on the other.

\section{The Required Elements of an FCA Claim Could Be Met}

In order to state a claim under the FCA, the relator or the government must show that (1) a claim for payment was submitted to the government; (2) the claim was false or fraudulent; and (3) the defendant knew or should have known of its falsity. ${ }^{1.5}$ Furthermore, a relator must also show that he did not rely on publicly available information or that he is an original source of that information. While whether a claim under the FCA would be successful is highly fact-dependent, in the right circumstances a suit could be brought.

\section{An IRB causes a claim for payment to be submitted.}

The primary purpose of an IRB is to evaluate research to ensure that it meets the requirements of federal funding. Without the approval of the IRB, the government would never expend funds on the research protocol in question. By certifying that the research meets federal guidelines, the IRB has made a statement or created a report, the purpose of which is to get a claim paid or approved by the federal government. ${ }^{1.5}$ Although the IRB itself does not receive funding, who actually receives the money is irrelevant for purposes of the FCA. ${ }^{137}$

134 S Rep No 99-345 (cited in note 47) (describing the experience of an individual who was faced with either losing his job or keeping quiet as to falsifying time cards, and noting that fear of reprisal was the second most cited reason for not reporting false claims).

135 See text accompanying note 55 .

13631 USC \$3729(a)(2).

137 Boese, Civil False Claims $\$ 2.07[\mathrm{~A}]$ at 2-184.2 (cited in note 55) ("Courts have found a defendant liable for 'causing' another to submit a false claim even if this defendant neither seeks nor obtains federal funds on his own behalf."). 
2. A claim submitted by the IRB could be false or fraudulent: application of the implied certification doctrine.

By approving research that is in violation of the federal regulations, the IRB would be both presenting false information and causing a fraudulent claim to be submitted to the government. For instance, if an IRB knew that a researcher was not properly obtaining informed consent, to approve the research and thus impliedly certify that the research meets federal regulations would be to make a false statement. Consequently, the claim submitted to the federal government, which must comply with the federal regulations in order to be paid, would be fraudulent.

In effect, any research that was approved but that violated the federal regulations could present an actionable claim under the FCA: by approving research, the IRB impliedly certifies that the research meets federal guidelines for funding. Courts have been reluctant, however, to allow claims to proceed under an implied certification theory, fearing that technical violations would become a basis for liability. ${ }^{138}$ Courts have also feared that the implied certification theory fails to recognize that defendants may not fully understand the regulations at issue and that the government may not have made a funding decision based on the false or fraudulent information contained within the claim. To avert these possibilities, courts have limited implied certification claims to those that are based on a material violation or those that are required as a condition of government funding.

a) The implied certification doctrine. An implied certification theory is needed to prosecute most healthcare fraud. ${ }^{139}$ Because part of the purpose in amending the FCA was to reach healthcare fraud more effectively, ${ }^{10}$ it is reasonable to assume that Congress intended some sort of implied certification theory. Courts should, however, limit the breadth of the implied certification doctrine to instances in which the violation of the regulations would have been material to a government decision to fund the research. ${ }^{141}$ This limitation is consistent with congressional intent, because Congress intended to "recover losses sustained as a result of fraud against the government." ernment would have funded IRB research with knowledge of technical violations of federal regulations, it is difficult to see why the suit would fulfill the purpose of the FCA. Indeed, it is generally the case that the federal government would continue to fund research; OHRP

\footnotetext{
138 For a detailed discussion of implied certification, see Part II.B.2.

139 Rabecs, 2001 Detroit Coll L Rev at 4 (cited in note 87).

140 See Part III.B.

141 See notes 109-14 and accompanying text.

142 S Rep No 99-345 at 1 (cited in note 48) (emphasis added).
} 
rarely suspends federal funding of human subjects research ${ }^{143}$ and usually does so only when violations have been found that threaten the welfare of human subjects. Furthermore, the clear weight of authority supports some restriction on the broad view of the doctrine set forth in $A b-T e c h .^{14+}$

Limiting implied certification to violations that would have changed the funding decision would also accord with the judicially imposed requirement of materiality in proving a violation of the FCA statute itself. ${ }^{245}$ While there is no materiality requirement in the text of the FCA, courts have reasoned that only false statements or claims that would have influenced the decision of the government should be actionable under the FCA. ${ }^{146}$ If courts are willing to overlook nonmaterial false statements as de minimis infractions or to hold that nonmaterial statements lack a necessary element of causation, it is difficult to imagine why they should not overlook the failure of an IRB to comply with technical requirements of the federal regulations that are nonmaterial.

Requiring that a violation of the federal regulations be material in order to allow an implied certification claim also makes sense as a matter of policy. As noted above, allowing any suit against the IRB has negative consequences that should be weighed against the benefit gained from allowing the suit. ${ }^{147}$ If courts were to allow FCA suits based on technical violations of the federal regulations, it is difficult to see what value this would have for human subjects protections. Generally, if the violation is based on a technical requirement, human subjects are not endangered by the violation. In addition, government funding has not been lost or improperly spent since the government would, if the court were to hold that the violation was not material, have funded the research anyway. For instance, while OHRP cited the Hopkins IRB that approved the protocol at issue in the Roche case

143 OHRP, Protecting Human Research Subjects, 2, OEI-01-97-00197 at 2 (Apr 2000) (noting that between June 1998 and March 2000 OHRP suspended federal funding at only seven research institutions, despite the increase in on-site investigations during the same period).

144 Richard J. Webber, Exploring the Outer Boundaries of False Claims Act Liability: Implied Certifications and Materiality, 36 Procurement L 14, 15 (Winter 2001).

145 Berge $v$ Board of Trustees of the University of Alabama, 104 F3d 1453, 1459 (4th Cir 1997) (holding that "[i]f previously unclear, we now make explicit that the current civil False Claims Act imposes a materiality requirement" and deciding that false statements made to the NIH in support of a research grant proposal were not material and therefore not actionable under the FCA). But see Cantekin v University of Pittsburgh, 192 F3d 402, 415 (3d Cir 1999) (suggesting that the reasoning of the Supreme Court in Neder $v$ United States, 527 US 1, 23 n 7 (1999), might argue against a materiality requirement).

146 Harrison $v$ Westinghouse Savannah River Co, 176 F3d 776, 785 (4th Cir 1999) (noting that materiality depends upon "whether the false statement has a natural tendency to influence agency action or is capable of influencing agency action"'), quoting Berge, 104 F3d at 1459.

147 See Part III.B. 
for failing to keep minutes of the IRB meetings, ${ }^{48}$ it is difficult to see how this imperiled the safety of human participants or affected the decision of the government to fund the research. On the other hand, the alleged failure to gain a sufficient knowledge of the facts necessary to weigh the risks and benefits properly could result in harm to subjects and would be considered a material violation.

Furthermore, liability based on technical violations could cause IRBs to focus more heavily on ensuring that technical requirements are met at the expense of duties that more directly impact human subjects protections. While the technical requirements of the federal regulations should not be minimized, other mechanisms, such as oversight by OHRP, are in place to ensure those requirements are met. Finally, if the technical violation was one that was present in all of the IRB's approvals, such as a failure to maintain written records of its meetings, a relator could recover $\$ 5,000-\$ 10,000$ per research protocol approved. ${ }^{149}$ As noted, the costs of the claim should be proportional to the gain to the system in allowing the suit. Since the costs grow exponentially with the addition of each claim, and since these technical violations do not appreciably affect human subject protections, this is not a desirable result.

In addition to requiring that the regulatory violation be material, some courts have held that the statute must explicitly require that the regulatory guidelines be met. ${ }^{1.0}$ Even if a jurisdiction does limit the implied certification doctrine in this way, it is clear that meeting the requirements of the federal regulations is indeed explicitly required by law to receive funding for human subjects research. ${ }^{\text {Ist }}$ Therefore, while not all of the provisions of the federal regulations may be relevant to a governmental decision to fund research, compliance with the regulations in general certainly is.

b) IRBs are familiar with the requirements of the federal regulations. One reason courts have been unwilling to imply certification is the fear that the defendant did not know or understand the requirements of the regulations upon which the FCA suit was based. ${ }^{152} \mathrm{Mem}-$ bers of the IRB, however, are expected to be much more familiar with the regulations governing human subjects research, both because the regulations are much less extensive than the Anti-Kickback and Stark

148 See text accompanying notes $39-42$.

149 This assumes, however, that courts do not require that a relator prove actual damages to the government. See text accompanying notes $67-74$.

150 See notes $115-17$ and accompanying text.

15142 USC $\$ 289$ (a) (1994); 45 CFR $\$ 46.103$ (a) (requiring that institutions engaged in federally funded research involving human subjects file written assurances that they will comply with the terms of the federal regulations).

152 See note 105 . 
laws and because the application of the regulations is their particular province. Therefore, there is less fear that someone could be held liable based on an arcane, highly technical regulation. Even the more technical requirements of the federal regulations of HHS are relatively straightforward, and the IRB could request the assistance of OHRP in their interpretation. In any event, members of IRBs, who undergo training by HHS in how to apply the federal regulations, ${ }^{153}$ should be knowledgeable in the application of the Common Rule.

\section{The scienter requirement.}

In most cases, it might be difficult to prove that an IRB has submitted a false claim with the requisite scienter. While IRBs may be negligent in failing to adhere to the federal regulations, it is probably rare that they purposefully violate them. ${ }^{154}$ Thus, in most cases an FCA claim based on actual knowledge would not be successful. There are, however, exceptions to this general rule. For instance, in Grimes $v$ Kennedy Krieger Institute, Inc, ${ }^{155}$ the IRB, in an apparent attempt to get around federal regulations discouraging the use of children as control groups, suggested that the researcher include language indicating that the children were actually receiving some therapeutic benefit. ${ }^{1.56}$ As the court noted, however, the change in wording did not affect whether the research actually had any therapeutic value for the children in the control group; the change was aimed at aiding "researchers in getting around federal regulations designed to protect children used as subjects in nontherapeutic research."157 It seems as though the IRB knew that the research did not actually meet federal guidelines, but nevertheless approved it for federal funding. While this may be an extraordinary case, it nevertheless illustrates that there are instances in which IRBs may meet the requisite scienter requirement under the FCA.

A plaintiff may also be able to show that the IRB was reckless in the application of the federal regulations. While commentators have urged against the use of the recklessness standard in the context of the Anti-Kickback and Stark laws, both of which are extremely complex, that complexity does not exist in this situation. Furthermore, as noted

153 OHRP, Federalwide Assurance of Protection of Human Subjects, available online at $<$ http://ohrp.osophs.dhhs.gov/humansubjects/assurance/filasurt.htm $>$ (visited Feb 8, 2002) (strongly recommending that IRB chairpersons complete training modules designed by OHRP to ensure that they are familiar with the federal regulations and that other IRB members undergo "relevant educational training").

154 See generally Grob, Institutional Review Boards: A System in Jeopardy (cited in note 131). While most commentators agreed that the system was in need of reform, most praised the performance of IRBs under the circumstances.

155366 Md 29,782 A2d 807 (Md App 2001).

$156782 \mathrm{~A} 2 \mathrm{~d}$ at 814.

157 Id. 
previously, IRBs have greater expertise in this area. For instance, in the Roche case, OHRP concluded that Hopkins failed to consider adequate information to determine the relative values of risk to the human subjects. Not only would this failure be material and thus meet the requirements of the implied certification doctrine, such a showing by a plaintiff in an action under the FCA might also be sufficient to show recklessness, since in other contexts the defendant's failure to gather adequate information to support a claim of payment was held to be reckless. While courts should not second-guess the IRB's reasoned determination that a particular protocol is sufficiently safe and valuable to warrant federal funding, a judicial determination that the IRB was reckless in failing to consider sufficient facts to make such a determination does not present the problem of a court's substituting its judgment for that of the IRB.

Courts should be sure to follow the admonition of Joslin $v$ Community Home Health of Maryland, Inc, ${ }^{158}$ and require that plaintiffs in a qui tam action prove the requisite scienter. Even if the IRB did violate the federal regulations, IRB members should not be held liable unless they knew that they were submitting a false claim or were reckless in not knowing.

Furthermore, the scienter requirement leaves IRB members the discretion to approve research. If courts apply a strict liability standard in determining IRB liability, courts could substitute their judgment for that of the IRB and conclude that the IRBs improperly calculated the risk of the research, that the consent forms were improperly worded, or otherwise disagree with matters normally left to the IRB's discretion. Insofar as IRBs are better able to apply the Common Rule, this is an undesirable outcome.

\section{Amount of damages.}

In FCA cases in which the regulatory violation would have affected the government's decision whether to fund the research, the amount of damages due the government would be relatively straightforward. In most instances, the actual damages would be the money the government paid as a result of the claim. Here, that amount should be the research grant. The government would then be entitled to three times that amount, plus $\$ 5,000-\$ 10,000$ per claim.

If, however, courts do not adopt the materiality restriction on the implied certification doctrine, and allow claims to go forward in which

158984 F Supp 374, 384-85 (D Md 1997) (declining to follow Ab-tech and stating that "while ignorance of the law is usually no excuse to justify one's actions, the FCA requires that a false statement be made with actual knowledge, deliberate ignorance, or reckless disregard of the statement's falsity"). 
the government would have funded the research notwithstanding the false claim, it may be difficult to show what damages were caused. For instance, if the IRB failed to keep written records of its meetings, but the research would have been approved by the government anyway, there would not seem to be any pecuniary loss to the government. While most courts would treat the $\$ 5,000-\$ 10,000$ per claim penalty as a sort of liquidated damages provision, courts that require proving actual damages as an element of the FCA might not allow a suit based only on technical violations.

\section{Jurisdictional issues.}

As discussed previously, if a relator relies on public information, the court generally lacks subject matter jurisdiction over the FCA claim. ${ }^{159}$ In the IRB context, if a relator relies on a report filed by OHRP, the court would lack subject matter jurisdiction over his claim. Indeed, most courts require that the information be released in one of the sources explicitly mentioned in the statute ${ }^{160}$ when deciding whether they have subject matter jurisdiction, ${ }^{161}$ although an OHRP report would certainly qualify as an administrative report and thus could potentially raise the jurisdictional bar.

In addition, it is probable that the elements of fraud would be included in the OHRP report: ${ }^{162}$ that the IRB did not adhere to the federal regulations and that it improperly approved research that was funded by the federal government. Both of these were detailed in the OHRP report of the Johns Hopkins research. ${ }^{1.3}$ Inclusion in the OHRP report of the critical elements of the fraud would count as a public disclosure for purposes of the FCA, depriving the court of jurisdiction.

While most research subjects would probably not have sufficient information as to the workings of the IRB that approved their research project to bring a suit without the benefit of an OHRP report,

159 See Part II.A.4.

16031 USC $\$ 3730(\mathrm{e})(4)(\mathrm{A})$ (including a "criminal, civil or administrative hearing. . . congressional, administrative or Governmental Accounting Office report, hearing, audit or investigation, ... [and] the news media" as potential sources).

161 Williams v NEC Corp, 931 F2d 1493, 1499 (11th Cir 1991) (finding that the methods of "public disclosure" set forth in 31 USC \$3730(e)(4)(A) are exclusive of the types of public disclosure that would defeat jurisdiction under that section); LeBlanc $v$ Raytheon Co, 913 F2d 17,20 (1st Cir 1990) (holding that the only allowable forms of public disclosure are those outlined in the statute); Phipps $v$ Comprehensive Community Development Corp, 152 F Supp 2d 443, 453 (S D NY 2001) (stating that the first part of a two-part test for determining if a court has subject matter jurisdiction is to determine whether the "allegations or transactions" on which the qui tam action is based were publicly disclosed in one of the manners listed in the statute).

162 See notes 78-83 and accompanying text.

163 Letter from Patrick J. McNeilly (cited in note 40). 
others associated with the IRB might be classified as an "original source" and be able to file suit. ${ }^{164}$ For instance, in the Robertson case, a nurse familiar with the study brought the improper activities of the IRB to the government's attention. ${ }^{155}$ OHRP eventually issued a report detailing those activities and concluded that they did in fact violate the federal regulations. The nurse met the requirements of an original source notwithstanding the OHRP report: she had direct and independent knowledge of the IRB's actions without the OHRP report and she disclosed the information to the government. Thus, she could have brought a qui tam action, the OHRP report notwithstanding. The public disclosure bar would not apply in her case, or others like it, if a suit were brought under the FCA.

\section{CONCLUSION}

The False Claims Act provides a viable cause of action for those seeking to sue an IRB for a violation of the federal regulations governing human subjects research. Although varying interpretations of the FCA will determine which claims are actionable, some claims could be successful even under the most conservative interpretation. The most difficult barriers to overcome in bringing an FCA suit are showing that the IRB knew it was approving research in violation of the federal regulations, or was reckless in granting its approval, and that the relator did not rely on publicly available information in bringing the suit. Furthermore, courts should adopt an interpretation of the FCA that requires that the violation be material to the government's decision, both to avoid the possible requirement that actual damages be shown and to prevent disproportionately large awards under the penalty provisions. Nevertheless, because a plaintiff does not have to prove the same kind of injury required by the traditional tort suit, a claim based on the FCA may present an attractive option to the potential litigant. Finally, in these limited circumstances, the use of the FCA may promote a high level of protection of human subjects of biomedical and behavioral research in the United States.

164 See notes 84-86 and accompanying text.

165 See notes 33-38 and accompanying text. 